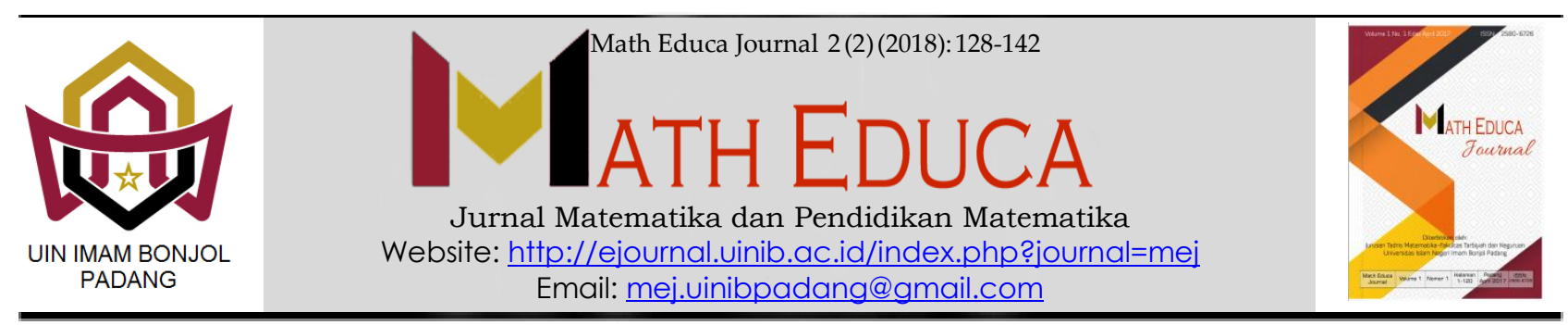

\title{
MOTIVASI DAN KEMAMPUAN PENALARAN MATEMATIS SISWA DENGAN PEMBELAJARAN KOOPERATIF TIPE PAIR CHECK DISERTAI REWARD PADA MATERI FUNGSI
}

\author{
'Rivdya Eliza, ${ }^{2}$ Khadijah, ${ }^{3}$ Utari Wulandari \\ 'Tadris Matematika, Fakultas Tarbiyah dan Keguruan, UIN Imam Bonjol Padang, Indonesia \\ 2Matematika, Fakultas Matematika dan Ilmu Pengetahuan Alam, Univeritas Andalas, Indonesia \\ Email: ${ }^{1}$ rivdyaeliza@gmail.com, ${ }^{2 k h a d i j a h i a i n @ g m a i l . c o m, ~}{ }^{3}$ wulandariutari872@gmail.com
}

Received: August 2018; Accepted: September 2018; Published: October 2018

\begin{abstract}
Abstrak
Tujuan dari penelitian ini adalah 1) Untuk mengetahui motivasi belajar matematika siswa yang diajar dengan menggunakan model pembelajaran kooperatif tipe Pair Check disertai Reward lebih tinggi dari motivasi siswa yang diajar dengan pembelajaran konvensional. 2) Untuk mengetahui kemampuan penalaran matematis siswa yang diajar dengan menggunakan model pembelajaran kooperatif tipe Pair Check disertai Reward pada materi fungsi, lebih tinggi dari kemampuan penalaran matematis siswa yang diajar dengan pembelajaran konvensional. Jenis penelitian ini eksperimen semu (Quasi Experimental Research) dengan rancangan penelitian Randomized Control Group Only Design. Populasi dalam penelitian ini adalah seluruh siswa kelas VIII SMPN 19 Padang. Untuk mendapatkan kelas sampel dilakukan uji normalitas, homogenitas dan kesamaan rata-rata kelas yang terpilih sebagai kelas eksperimen adalah kelas VIII.5 dan kelas kontrol adalah kelas VIII.3. Hasil penelitian menunjukkan 1) Motivasi belajar siswa yang diajar menggunakan model pembelajaran kooperatif tipe Pair Check disertai Reward, lebih tinggi dari motivasi siswa yang diajar menggunakan pembelajaran konvensional, uji hipotesis yaitu $t_{\text {hitung }}(7.034)>t_{\text {tabel }}(1.67)$. 2) Kemampuan penalaran matematis siswa setelah diajar dengan model pembelajaran kooperatif tipe Pair Check disertai Reward lebih tinggi dari pada kemampuan penalaran matematis siswa yang diajar menggunakan pembelajaran konvensional. Terlihat dari rata-rata nilai tes kelas eksperimen 80,16 dan rata-rata nilai tes kelas kontrol 74,13. Setelah dilakukan uji hipotesis, diperoleh $t_{\text {hitung }}>t_{\text {tabel }}(1,867>1,67)$ pada selang kepercayaan $95 \%$. Sehingga dapat disimpulkan kemampuan penalaran matematis siswa kelas VIII SMPN 19 Padang yang diajar dengan model pembelajaran Kooperatif tipe Pair Check disertai pemberian reward lebih tinggi dari yang diajar dengan menggunakan pembelajaran konvensional.
\end{abstract}

Kata Kunci: Kemampuan Penalaran matematis dan Motivasi, Model Kooperatif Tipe Pair Check, Reward, Fungsi, Matematika

\section{Abstract}

The purpose of this study is 1) To know the motivation to learn mathematics of taught by using cooperative learning model type Pair Check with reward higher than student motivation taught by convensional learning,

\footnotetext{
${ }^{*}$ Corresponding author.

Peer review under responsibility UIN Imam Bonjol Padang.

(c) 2018 UIN Imam Bonjol Padang. All rights reserved. 
and 2) To know the mathematical reasoning ability which was taught by using cooperative learning model type Pair Check with reward on material function is higher than students mathematical reasoning ability taught by convensional learning. This type of research is Quasi Experimental Research with Randomized Control Group Only Design. The population in this study is all eighth grade student of SMPN 19 Padang. In obtaining the sample class it is need to be done normality, homogeneity and equality of classroom average tests the class selected as the experimental class is VIII. 5 class and the control class is VIII.3. The result of the research shows that 1) learning motivation of students which was taught by using cooperative learning Pair Check model with Reward is higher than student's motivation taught by convensional learning. Hypothesis test that is t-score (7.034) > t-table (1.67), 2) students' mathematical reasoning ability after being taught by cooperative model type Pair Check with reward is higher than the students' mathematical reasoning abilities taught by conventional learning models. Seen from the average score of the experimental class test score of 80.16 and the average of the control class test score of 74.13. After hypothesis testing using $t$-test, obtained $t$ score $>$ t-table $(1.867>1.67)$ at $95 \%$. So it can be student mathematical reasoning ability of class VIII SMPN 19 Padang which is taught by cooperative learning model type Pair Check with reward is higher than taught by using conventional learning.

Keywords: Mathematic Reasoning Ability And Student Motivation, Model Cooperative Type Pair Check, Reward Fungsi, And Mathematic

\section{PENDAHULUAN}

Pada dasarnya pertumbuhan dan perkembangan siswa bergantung pada dua unsur yang saling mempengaruhi, yakni bakat yang dimiliki oleh siswa sejak lahir, dan lingkungan yang mempengaruhi hingga bakat itu tumbuh dan berkembang. Kendatipun dua unsur tersebut sama pentingnya, namun ada kemungkinan pertumbuhan dan perkembangan itu disebabkan oleh bakat saja atau pengaruh lingkungan saja (Hamalik 1999:3).

Matematika adalah salah satu mata pelajaran yang wajib diajarkan pada setiap jenjang pendidikan, mulai dari tingkat sekolah dasar hingga perguruan tinggi. Yang mempunyai fungsi sebagai suatu struktur, sebagai kumpulan sistem, dan sebagai ratunya ilmu.

Pembelajaran matematika adalah suatu proses belajar yang dibangun oleh guru untuk mengembangkan kreativitas berfikir siswa yang dapat meningkatkan kemampuan berfikir siswa, serta dapat meningkatkan kemampuan

mengkonstruksi pengetahuan baru sebagai upaya meningkatkan penguasaan yang baik terhadap materi matematika. Jadi pembelajaran matematika suatu belajar mengajar yang mengandung dua jenis kegiatan yang tidak terpisahkan.

Jadi tujuan dari pendidikan matematika pada jenjang pendidikan dasar dan menengah adalah menekankan pada penataan nalar dan pembentukan kepribadian(sikap) siswa agar dapat menggunakan atau menerapkan matematika dalam kehidupannya. Untuk itu matematika dipandang sebagai ilmu dasar yang sangat penting dikuasai oleh siapapun untuk belajar dalam perubahan zaman. Dengan demikian, matematika mata pelajaran yang sangat penting dalam pendidikan dan wajib dipelajari pada setiap jenjang pendidikan (Shadiq, 2009: 2). 
Berdasarkan hasil observasi yang dilakukan di SMP Negeri 19 Padang pada tanggal 25-26 April tahun 2017, diantaranya adalah siswa mengalami kesulitan bagaimana mengaplikasikan konsep ke soal-soal yang diberikan guru sehingga sedikit siswa yang dapat menyelesaikan soal-soal dengan benar. Begitupun, soal yang diberikan berkaitan dengan aspek penalaran sehingga siswa masih membutuhkan banyak arahan dari guru dalam menyelesaikannya, akibatnya siswa lebih cenderung menyalin jawaban temannya yang lebih pintar dan kurangnya motivasi siswa saat mengikuti pembelajaran matematika, terbukti pada saat mengikuti pembelajaran matematika, siswa kurang aktif dan selalu keluar masuk saat pembelajaran berlangsung, karena proses pembelajaran banyak didominasi oleh guru.

Berdasarkan hasil wawancara dengan guru Matematika dan beberapa orang siswa di kelas VIII SMPN 19 Padang diperoleh informasi bahwa guru lebih cenderung menggunakan metode konvensional dalam proses pembelajaran sehingga siswa belum terarahkan untuk memahami sendiri konsep-konsep matematika terutama pada mata pelajaran relasi dan fungsi. Metode konvensional tersebut belum mampu mengembangkan kemampuan karena siswa hanya cenderung menghafalkan konsep-konsep yang dipelajarinya tanpa memahami dengan benar. Akibatnya, penguasaan siswa terhadap konsep-konsep tersebut menjadi rendah.
Dengan adanya permasalahan di atas tujuan pembelajaran tidak tercapai secara maksimal dan berpengaruh terhadap motivasi siswa dalam mengikuti pembelajaran khususnya dalam belajar matematika pada materi fungsi, dan berdampak kepada kemampuan penalaran matematis siswa. Terbukti dengan hasil ulangan matematika siswa pada materi fungsi masih di bawah kriteria ketuntasan minimum (KKM) yaitu 80. Rendahnya kemampuan penalaran matematis siswa terutama pada materi fungsi, Juga dapat dilihat dari hasil latihan yang memuat kemampuan penalaran. Contoh jawaban siswa yang tidak sesuai diantaranya dapat dilihat pada Gambar 1 dan Gambar 2.

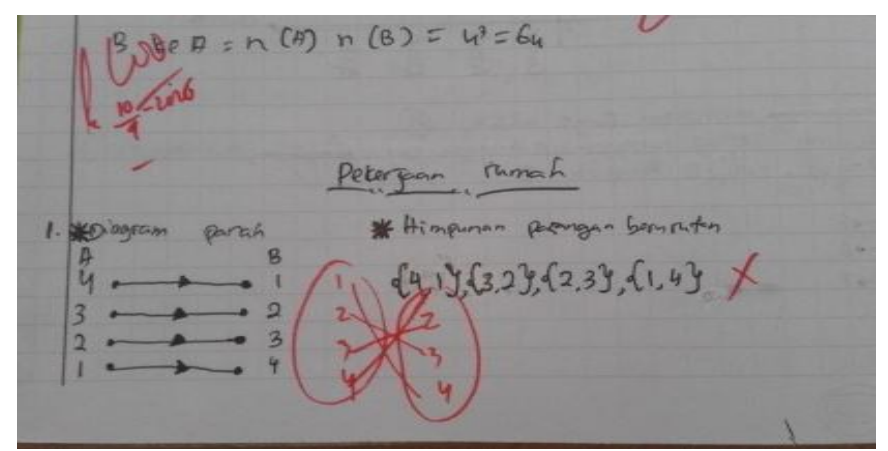

Gambar 1. Contoh Salah Satu Jawaban Siswa untuk Soal Penalaran.

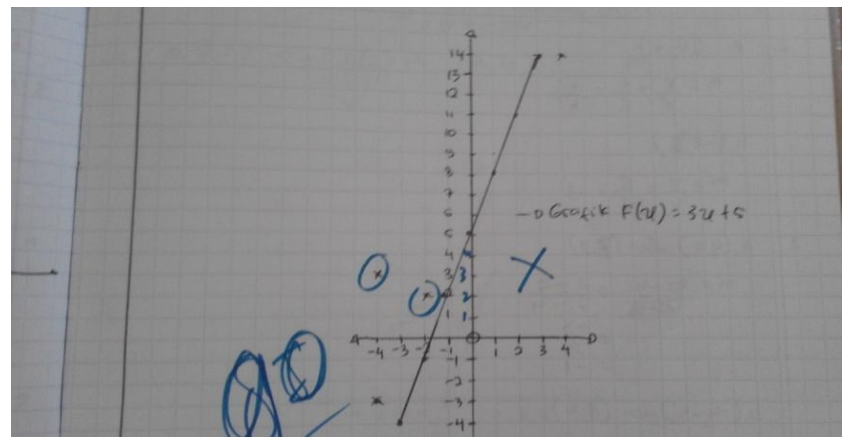

Gambar 2. Contoh Salah Satu Jawaban Siswa untuk Soal Penalaran.

Dari latihan siswa yang telah dipaparkan di atas terdapat beberapa dari indikator penalaran yaitu menyajikan pernyataan 
matematika secara lisan, tertulis, gambar, dan diagram dan Kemampuan menyusun bukti, memberikan alasan/bukti terhadap kebenaran solusi, memanipulasi matematika, yang belum terpenuhi.

Pada jawaban gambar yang pertama terdapat indikator penalaran yaitu menyajikan pernyataan matematika secara lisan, tertulis, gambar, dan diagram. Namun pada jawaban latihan siswa tersebut cukup terpenuhi, tetapi ada beberapa yang kurang tepat salah satunya tidak membuat diagram dan untuk menyusun bukti dari jawaban kurang tepat seperti pasangan berurutan seharusnya $\{(1,4)(2,3)(3,2)$, $(4,1)\}$. Pada Gambar 2, terdapat indikator penalaran yaitu menyajikan gambar, diagram yang kurang tepat.

Berdasarkan hasil latihan siswa yang telah dicantumkan diatas bahwasanya beberapa dari siswa tidak mengerti dengan pembelajaran yang telah diajarkan apalagi menyangkut soal yang mengacu kepada penalaran. Melihat kondisi tersebut, bahwasanya kemampuan penalaran matematika siswa pada mata pelajaran matematika khususnya materi fungsi belum tercapai. Model pembelajaran yang dapat meningkatkan motivasi dan kemampuan penalaran matematis siswa adalah model pembelajaran Pair Check. Pair Check merupakan model pembelajaran berkelompok antar dua orang atau berpasangan dipopulerkan oleh Spencer Kagan pada tahun 1990. Model ini menerapkan pembelajaran kooperatif yang menuntut kemandirian dan kemampuan siswa dalam menyelesaikan persoalan. Model ini juga melatih tanggung jawab sosial siswa, kerja sama, dan kemampuan memberikan penilaian (Huda, 2014:211). Langkah-langkah pelaksanaan model Pair Check ; 1) Guru menjelaskan konsep tentang materi yang akan dipelajari. 2) Bagilah siswa di kelas ke dalam kelompok-kelompok yang terdiri dari 4 siswa. 3) Bagi lagi kelompok-kelompok tersebut menjadi berpasang-pasang. Jadi, akan ada partner A dan partner B pada kedua pasangan. 4) Berilah setiap pasangan sebuah LKS untuk dikerjakan. LKS terdiri dari beberapa soal (jumlahnya genap). 5) Berikutnya, berikan kesempatan pada partner $\mathrm{A}$ dan partner $\mathrm{B}$ untuk mengerjaan soal nomor 1 dan 2, sementara pelatih A dan B mengamati partner A dan B mengerjakan soal no 1 dan 2. 6) Setelah 2 soal diselesaikan, pasangan tersebut mengecek hasil pekerjaan mereka berdua dengan pasangan lain yang satu kelompok dengan mereka. 7) Pelatih dan parther saling bertukar peran, pelatih menjadi parthner dan parthner menjadi pelatih. 8) Langkah nomor 4, 5, dan 6 diulang lagi untuk menyelesaikan soal nomor 3 dan 4. 9) Setiap kelompok diberi waktu untuk persentasi kedepan dan dipilih secara acak oleh guru. 10) Guru memberikan reward pada kelompok yang memperoleh nilai terbanyak, guru juga dapat memberikan bimbingan bila kedua pasangan dalam kelompok mengalami kesulitan.

Kelebihan dari tipe pembelajaran Pair Check adalah; 1) Siswa akan aktif dalam proses pembelajaran 2) Siswa terlibat langsung dalam mengkaji dan menggali materi yang diajarkan 3) 
132 Math Educa Journal Volume 2 No. 2 Edisi Oktober 2018, pp. 128-142

meningkatkan kerja sama antar siswa 4) Mengetahui sendiri kemampuan belajar masingmasing siswa secara langsung. 5) Mempermudah guru dalam menyampaikan materi ajar, dan sekaligus meminimalisir perannanya. 6) Melatih siswa berkomunikasi dengan baik dengan teman sebangkunya.

Kelemahan dari pembelajaran tipe Pair Check adalah; 1) Membutuhkan kesiapan belajar dari guru dan siswa secara matang. 2) Kesiapan siswa untuk menjadi pelatih dan parthner yang jujur dan memahami soal dengan baik. 3) Membutuhkan waktu yang relatif lama yang benar-benar memadai

Di dalam pembelajaran ini disertai dengan pemberian penghargaan kepada kelompok atau siswa berupa reward, sehingga setiap kelompok atau siswa termotivasi untuk mendapatkannya. "Penghargaan sangat efektif untuk membangun motivasi ekstrinsik, penghargaan sangat efektif dalam menimbulkan dorongan untuk belajar" (Prayitno, 1989: 17).

Motivasi Intrinsik Adalah motivasi yang berasal dari dalam diri individu tanpa adanya rangsangan dari luar. Motivasi ekstrinsik adalah motivasi yang berasal dari luar misalnya pemberian pujian, pemberian nilai sampai pada pemberian hadiah. Uno (2012: 23) mengklasifikasikan indikator motivasi belajar sebagai berikut; 1) adanya hasrat dan keinginan berhasil. 2) adanya dorongan dan kebutuhan dalam belajar. 3) adanya harapan dan cita-cita masa depan.4) adanya penghargaan dalam belajar. 5) adanya kegiatan yang menarik dalam belajar. 6) adanya lingkungan belajar yang kondusif, sehingga memungkinkan seorang siswa dapat belajar dengan baik.

Namun peneliti hanya mengambil empat indikator yaitu adanya hasrat dan keinginan berhasil (keinginan), adanya dorongan dan kebutuhan dalam belajar, adanya harapan dan cita-cita masa depan (kesadaran), adanya kegiataan yang menarik dalam belajar (kesenangan) adanya penghargaan dalam belajar. Materi matematika dan penalaran matematika merupakan dua hal yang tidak dapat dipisahkan, yaitu materi matematika dipahami melalui penalaran, dan penalaran dipahami dan dilatih melalui belajar matematika, sehingga kemampuan penalaran matematis sangat penting dan dibutuhkan dalam mempelajari matematika.

"Penalaran merupakan suatu kegiatan, suatu proses atau suatu aktifitas berpikir untuk menarik kesimpulan atau membuat suatu pernyataan baru yang benar berdasarkan pada beberapa pernyataan yang kebenarannya telah dibuktikan atau diasumsikan sebelumnya" (Shadiq, 2004: 2). Indikator yang menunjukkan penalaran antara lain adalah: 1) Kemampuan menyajikan pernyataan matematika secara lisan, tertulis, gambar dan diagram. 2) Kemampuan mengajukan dugaan 3) kemampuan melakukan manipulasi matematika 4) Kemampuan menyusun bukti, memberikan alasan atau bukti terhadap kebenaran solusi. 5) Kemampuan menarik kesimpulan dari pernyataan. 6) Memeriksa kesahihan suatu argumen 7) 
Menemukan pola atau sifat dari gejala matematis untuk membuat generalisasi.

Berdasarkan kutipan di atas, maka kemampuan penalaran matematis yang akan diukur dalam penelitian ini ada empat indikator. Adapun empat indikator tersebut, yaitu (1) Kemampuan menyajikan pernyataan matematika secara lisan, tertulis, gambar; (2) Kemampuan mengajukan dugaan; (3) Kemampuan melakukan manipulasi matematika (4) Kemampuan menyusun bukti, memberikan alasan/ bukti terhadap kebenaran solusi.

\section{METODE PENELITIAN}

\section{Jenis Penelitian}

Jenis penelitian ini adalah penelitian eksperimen semu, dengan model rancangan yang digunakan adalah randomized control group only design. Menurut Arikunto (2006:87) rancangan penelitian randomized control group only design, dimana akan diambil dua kelas sebagai kelas eksperimen yang diberi perlakuan berupa model pembelajaran kooperatif tipe Pair Check dan kelas kontrol hanya menggunakan pembelajaran konvensional.

\section{Waktu dan Tempat Penelitian}

Penelitian dilaksanakan di SMPN 19 Padang Tahun Ajaran 2017/2018 di kelas VIII. Waktu penelitian dilaksanakan pada tanggal 21 agustus 2017 - 7 September 2017.

\section{Populasi dan Sampel}

Populasi adalah keseluruhan objek penelitian. (Arikunto, 2006:130). Sebelum dilakukan penelitian, maka terlebih dahulu ditentukan populasi penelitian. Populasi dalam penelitian ini adalah seluruh siswa kelas VIII.1VIII.5 SMP Negeri 19 Padang Tahun Pelajaran 2017/2018 yang berjumlah 157 siswa.

Menurut Sugiyono (2010:118) “Sampel adalah bagian dari jumlah dan karakteristik yang dimiliki oleh populasi tersebut". Setelah diperiksa dan ternyata populasi normal, homogen, dan mempunyai kesamaan rata-rata, maka pengambilan sampel dilakukan dengan pengundian nomor, dengan mengambil dua nomor secara acak (random sampling), dan ditetapkan bahwa kelas yang terambil pertama adalah kelas eksperimen (Kelas VIII.5) dan yang terambil kedua sebagai kelas kontrol (Kelas VIII.3).

\section{Prosedur Penelitian}

Prosedur penelitian dibagi atas tiga tahap, yaitu tahap persiapan, tahap pelaksanaan dan tahap akhir. Pada tahap persiapan, mempersiapkan semua yang diperlukan dalam penelitian seperti menetapkan jadwal penelitian, menentukan kelas sampel, dan mempersiapkan instrumen penelitian. Pada tahap pelaksanaan, pengumpulan data dan membuat RPP dilakukan pada kelas sampel.

Tahap akhir, diberikan tes pada kedua kelas sampel setelah pokok materi selesai diberikan. Tes yang diberikan berupa essay, membagikan angket motivasi. Mengolah data 
tes penalaran dan data angket motivasi dari kedua kelas sampel. Setelah selesai penelitian peneliti Meminta surat balasan dari sekolah yang isinya kapan terakhir penelitian di lakukan. Membuat laporan (skripsi) dari hasil yang diperoleh sesuai dengan teknik analisis yang digunakancara yang dilakukan pada kelas sampel tersebut.

\section{Instrumen Penelitian}

Instrumen penelitian yang digunakan dalam penelitian ini terdiri dari angket motivasi siswa dan soal test kemampuan penalaran. Penjelasan tentang masing-masing instrument adalah sebagai berikut:

\section{a. Angket}

Angket ini dimaksudkan untuk mengetahui apakah motivasi belajar siswa kelas VIII SMP Negeri 19 Padang pada mata pelajaran matematika Tahun Pelajaran 2017/2018 yang diajar dengan pembelajaran Tipe Pair Check lebih baik dibandingkan dengan motivasi belajar siswa yang diajar dengan pembelajaran konvensional, dengan aspeknya meliputi kesenangan, kemauan, kesadaran dan dorongan yang kemudian dijabarkan dalam butir-butir pernyataan dalam instrumen angket. Angket berpedoman pada skala Likert yang dinyatakan dalam Riduwan (2010: 86) bahwa alternatif jawaban adalah sangat setuju (SS), Setuju (S), Kurang Setuju (KS), tidak Setuju (TS), Sangat tidak Setuju (STS).
Adapun langkah-langkah pembuatan angket, membuat kisi-kisi berdasarkan indikator yang telah ditetapkan. Sebelum angket disusun, terlebih dahulu disusun yang menjadi indikator penentu angket. Uji coba angket dilakukan untuk mengetahui validitas dan reliabilitas instrument yang digunakan dan dilaksanakan di kelas VIII.4 pada tanggal 5 september 2017. Hasil analisis uji coba angket, menunjukkan seluruh item angket motivasi valid karena nilai koefisien validitas seluruhnya bernilai $r \geq 3$ (Sugiyono, 2006:213) Pengujian reliabilitas angket dilakukan dengan menggunakan rumus Alpha yang dikemukakan oleh Suharsimi Arikunto (2009:88);

$$
r_{11}=\left(\frac{n}{n-1}\right)\left(1-\frac{\sum \sigma_{i}^{2}}{\sigma_{\mathrm{t}}^{2}}\right)
$$

Di mana:

$\mathrm{r}_{11}$ : koefisiensi reliabilitas

$\mathrm{n} \quad$ : banyaknya butir angket

$\sum \sigma_{\mathrm{i}}^{2} \quad$ : jumlah varians setiap butir

$\sigma_{\mathrm{t}}^{2} \quad$ : Varians total

\section{b. Soal Tes Kemampuan Penalaran}

Soal tes yang akan diberikan adalah tes yang berbentuk tes uraian. Adapun langkahlangkah yang dilakukan dalam menyusun tes adalah menyusun kisi-kisi tes, menyusun tes sesuai dengan kisi-kisi tes yang telah dibuat, validitas tes. Suatu instrumen yang valid atau sahih mempunyai validitas yang tinggi. Sebuah tes memiliki validitas isi apabila mengukur tujuan khusus tertentu yang sejajar dengan materi yang di berikan. Melaksanakan uji coba tes, sebelum tes diberikan kepada siswa kelas sampel, terlebih dahulu 
dilakukan uji coba tes yang dilakukan di kelas lain. Uji coba dilakukan untuk menentukan daya pembeda, indeks kesukaran dan reliabilitas item yang akan diberikan tersebut mempunyai kualitas yang baik. Pemilihan kelompok siswa untuk uji coba ini adalah siswa yang kemampuannya tidak jauh berbeda dengan siswa kelas sampel. Dalam hal ini tes uji coba dilaksanakan di kelas VIII.4 pada tanggal 6 september 2017. Setelah uji coba dilakukan maka kegiatan selanjutnya adalah melakukan analisis butir soal, untuk melihat keberadaan soal-soal yang disusun baik atau tidak. Dalam melakukan analisa butir item soal, dilakukan daya pembeda soal menurut Arikunto (2006:211) "daya beda soal adalah kemampuan soal untuk membedakan siswa yang pandai (berkemampuan tinggi) dengan siswa yang kurang pandai (berkemampuan rendah)." Daya beda soal ditentukan dengan mencari indeks pembeda soal. Indeks pembeda soal merupakan angka yang menunjukkan perbedaan kelompok tinggi dan kelompok rendah.

\section{Teknik Pengumpulan Data, Pengolahan Data} dan Menyajikan Data

Teknik Pengumpulan data pada hasil belajar tes penalaran matematis menggunakan tes essay yang berjumlah 7 soal, dan sebaran angket yang berjumlah 22 item yang valid. Pada saat tes berlangsung siswa harus mengikuti aturan-aturan yang telah ditetapkan Siswa menjawab soal pada lembar jawaban yang telah disediakan, setelah siswa menyelesaikan tes, maka lembar jawaban dikumpulkan.

Teknik Pengolahan Data Menghitung skor penalaran matematis siswa Teknik pengolah data kemampuan penalaran metematis siswa didapat dengan memberi skor pada setiap soal yang dikerjakan oleh siswa dengan mencocokkan kunci jawaban yang telah dibuat.

Penilaian jawaban tes akhir siswa berdasarkan rubrik penalaran. Untuk menghitung nilai akhir siswa digunakan rumus berikut sebagai berikut:

$$
\text { Nilai akhir }=\frac{\text { skor yang diperoleh siswa }}{\text { skor maksimum }} \times 100
$$

Data yang telah dikumpulkan jika telah memenuhi syarat maka perlu diolah. Pengolahan data merupakan kegiatan terpenting dalam proses dan kegiatan penelitian. Pengolahan data yang dilakukan, lembar jawaban disusun dengan mengurutkan dari nilai yang terendah sampai nilai yang tinggi. Menentukan nilai rata-rata, standar deviasi dan variansi dengan rumus:

$$
\bar{x}=\frac{\sum x_{i}}{n} \quad S=\sqrt{\frac{n \sum x_{i}^{2}-\left(\sum x_{i}\right)^{2}}{n(n-1)}}
$$

keterangan : $\bar{x}=$ Rata-rata nilai siswa

${ }_{i}=$ Nilai siswa ke-i

$n=$ Jumlah siswa

$S=$ Standar deviasi 
Pengolahan data angket untuk selanjutnya. Bentuk penyajian data pada mengetahui derajat pencapaian motivasi juga penelitian ini menggunakan tabel. Tabel dapatmenggunakan rumus Syahron Lubis (2011:8 digunakan untuk menyajikan data rata-rata 7):

$$
D P=\frac{\sum X}{N \times \sum \text { Item } \times \text { Skala Terting gi }}
$$

Keterangan:

$\mathrm{DP}=$ Derajat Pencapaian

$\sum X=$ Total Skor Hasil Pengukuran

$\sum$ item = Jumlah Butir Instrumen

$n \quad=$ Jumlah Responden

Selain menggunakan analisis data deskriptif juga digunakan analisis perbedaan untuk uji hipotesis dengan menggunakan rumus t-test. Sebelum dilakukan uji hipotesis maka terlebih dahulu data diubah dari ordinal ke interval, dengan metode suksesif interval (Method of Successive Interval /MSI). Metode suksesif interval merupakan proses mengubah data ordinal menjadi data interval. Adapun proses mengubah data berskala ordinal menjadi data berskala interval (Sarwono, 2017:1), dilakukan dengan 1) menghitung frekuensi, 2) menentukan proporsi, 3) menghitung proporsi kumulatif, 4) menghitung nilai $z$, 5) menghitung nilai densitas fungsi $z, 6$ ) menghitung scale value, 7) menghitung penskalaan.

Teknik penyajian data. Data yang diperoleh dari proses pengumpulan data pada umumnya masih berupa data mentah yang belum teratur. Agar data tersebut menjadi lebih bermakna, maka dilakukan proses menyajikan data kedalam bentuk-bentuk tertentu agar lebih berarti dan mudah untuk penggunaan kemampuan kemampuan penalaran matematis dan motivasi siswa per-indikator.

\section{Teknik Analisis Data}

Teknik analisis data menggunakan analisis data awal dan analisis data akhir. Analisis data awal yaitu menggunakan uji normalitas dan uji homogenitas dan uji kesamaan rata-rata untuk menentukan kelas sampel yang akan diberi perlakukan. Data yang diuji adalah data nilai Ulangan Tengah Semester kelas eksperimen, kontrol, dan uji coba. Sedangkan analisis data akhir yaitu, menggunakan uji normalitas homogenitas dan uji hipotesis, data yang diuji adalah data nilai tes evaluasi kemampuan penalaran kelas eksperimen dan kontrol. Begitupun dengan analisis data angket motivasi siswa yaitu uji normalitas, homogenitas dan hipotesis.

\section{HASIL PENELITIAN DAN PEMBAHASAN}

Berdasarkan penelitian di SMPN 19 Padang tahun ajaran 2017/2018, diperoleh data motivasi belajar dan kemampuan penalaran matematis siswa. Kemampuan penalaran matematis siswa diperoleh dari tes akhir yang diberikan pada kelas sampel dengan pokok bahasan Fungsi.

Pada penelitian di SMPN 19 Padang peneliti menggunakan model pembelajaran kooperatif tipe Pair Check dan pemberian 
penghargaan/reward kepada kelompok atau tim yang mendapatkan skor tertinggi. Penghargaan atau reward yang diberikan berupa hadiah. Skor penghargaan pada masing-masing kelompok dapat dilihat pada Tabel 1.1

Tabel 1.1 Penghargaan Kelompok Pada Pertemuan 1 sampai 5 Menggunakan LKS
Tabel 1.2 menjelaskan indikator pertama motivasi belajar matematika siswa yang meliputi kesenangan (pernyataan no $1,2,3,4,16,18$ ) dan persentase indikator pertama pada kelas eksperimen yaitu $87,19 \%$ dengan criteria baik, sedangkan pada kelas kontrol yaitu $66,25 \%$ dengan kriteria sedang. Indikator kedua keinginan siswa terdapat pada pernyataan no.

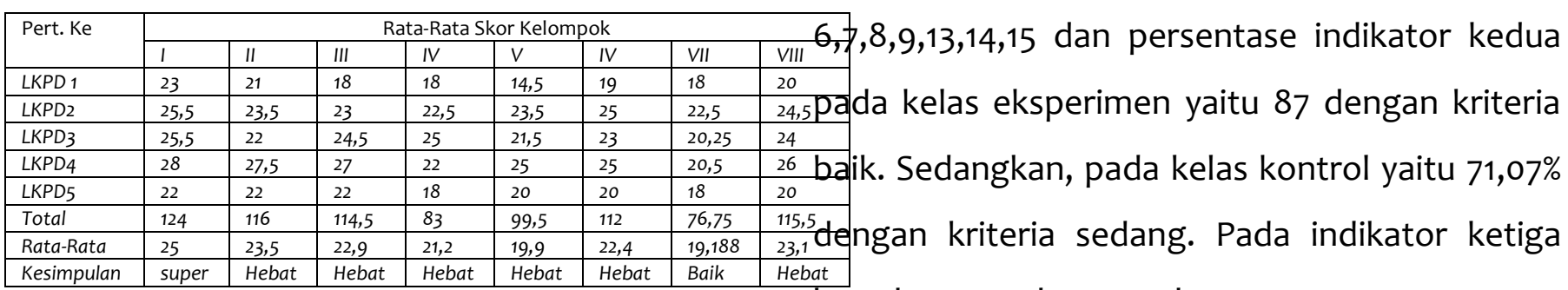
kesadaran terdapat pada pernyatan no 5,10,11,12

\section{A. Angket motivasi belajar siswa}

Setelah siswa mengisi lembar angket sesuai dengan indikator motivasi belajar siswa yaitu Perasaan senang terhadap pelajaran, keinginan dalam belajar, kesadaran siswa dalam belajar, dorongan dari orang tua, guru dan hadiah. Dengan menggunakan rumus menghitung nilai motivasi belajar siswa, sehingga diperoleh persentase dari tiap indikator dapat dilihat pada Tabel 1.2:

\section{Tabel 1.2 Persentase Nilai Setiap Indikator Motivasi Belajar Siswa}

\begin{tabular}{|c|l|l|l|l|l|l|l|}
\hline \multicolumn{1}{|c|}{ Indikator } & Nomor & \multicolumn{2}{|l|}{ Jumlah Skor } & \multicolumn{2}{l|}{$\begin{array}{l}\text { Pencapaian } \\
(\%)\end{array}$} & \multicolumn{2}{l|}{ Kiriteria } \\
\hline Motivasi & Peryataan & Eksp. & $\begin{array}{l}\text { Kontr } \\
.\end{array}$ & Eksp. & Kontr. & Eksp. & Kontr. \\
\hline 1. Kesenangan & $\begin{array}{l}1,2,3,4,16,1 \\
8\end{array}$ & 837 & 636 & 87,19 & 66,25 & Baik & Sedang \\
\hline 2. Keinginan & $\begin{array}{l}6,7,8,9,13,1 \\
4,15\end{array}$ & 974 & 796 & 87 & 71,07 & Baik & Sedang \\
\hline 3. Kesadaran & $5,10,11,12$ & 578 & 493 & 90,31 & 77,03 & $\begin{array}{l}\text { Sang } \\
\text { at } \\
\text { Baik }\end{array}$ & Sedang \\
\hline 4. Dorongan & $19,20,21,22$ & 550 & 518 & 86 & 81 & Baik & Baik \\
\hline 5. Hadiah & 17 & 139 & 125 & 87 & 78,13 & Baik & Sedang \\
\hline Total & & 3078 & 2568 & 87,45 & 74,68 & Baik & Sedang \\
\hline
\end{tabular}

dan persentase indikator ketiga pada kelas eksperimen yaitu 90,31\% dengan kriteria sangat baik, sedangkan pada kelas kontol yaitu 77,03\% dengan kriteria sedang. Pada indikator keempat dorongan dari orang tua dan guru terdapat pada pernyatan no 19 sampai 22, persentase indikator keempat pada kelas eksperimen yaitu $86 \%$ dengan kriteria baik, sedangkan pada kelas kontrol 81 dengan criteria baik. Pada indikator kelima; hadiah terdapat pada pernyataan no. 17, persentase indikator kelima pada kelas eksperimen yaitu $87 \%$ dengan kriteria baik, sedangkan pada kelas kontrol yaitu 78,13 dengan kriteria sedang. Dari gambar di atas dijelaskan bahwa motivasi belajar matematika siswa untuk setiap indikator di kelas eksperimen lebih tinggi dari pada skor motivasi di kelas kontrol. Dalam bentuk grafik dapat dilihat pada Gambar 


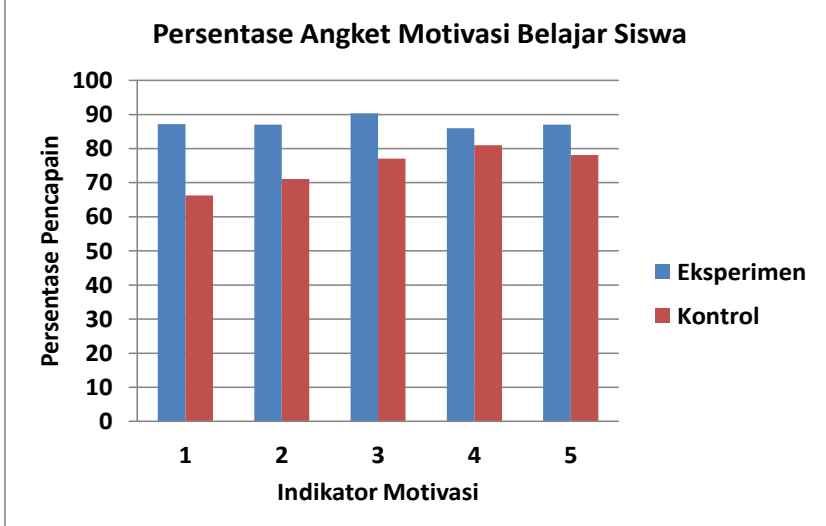

Gambar 1.1. Grafik Persentase Motivasi Belajar Matematika Siswa

Keterangan

1. Kesenangan

2. Keinginan siswa

3. Kesadaran siswa

4. Dorongan

5. Hadiah

Berdasarkan analisis di atas dapat diketahui bahwa motivasi belajar matematika siswa kelas eksperimen yang diajar dengan model pembelajaran kooperatif tipe Pair Check yaitu $87,45 \%$ dengan kriteria baik sedangkan pada kelas kontrol $74,68 \%$ dengan kriteria cukup.

Selanjutnya untuk menguji hipotesis motivasi belajar siswa dikelas eksperimen dan kelas kontrol dilakukan dengan cara memindahkan data ordinal ke data interval terlebih dahulu. Data angket sudah berbentuk data interval sesuai dengan perhitungan transformasi data ordinal ke data interval (Statistika,08/2012,Transformasi dataordinal men jadi interval). Sebelum diuji hipotesis terlebih dahulu uji normalitas dan homogenitas. Hasil uji normalitas data motivasi belajar siswa di kelas eksperimen adalah $0.0752<0,1516$ di kelas kontrol adalah 0,0745 0,1565 karena $\mathrm{L}_{0}<\mathrm{L}_{\text {tabel }}$
Maka data normal. Uji Homogenitas variansi dilakukan untuk melihat apakah kedua kelompok data mempunyai variansi yang homogen atau tidak. Pengujian dilakukan dengan menggunakan uji F.

$\mathrm{F}=\frac{S_{2}{ }^{2}}{S_{1}{ }^{2}}=F=\frac{13.739}{9.235}=1.4877 \approx 1.49$

Berdasarkan tabel distribusi $F$ didapatkan nilai $F_{\text {tabel }}$ untuk taraf nyata $\alpha=0,05$ dan derajat kebebasan $(d f)=\left(n_{1}-1, n_{2}-1\right)=(32,32)$ adalah 1.67 . Maka diperoleh $F_{\text {hitung }}<F_{\left(\alpha ; v_{1}, v_{2}\right)}=1.49<$ 1.84

Uji Hipotesis motivasi belajar siswa kelas eksperimen lebih tinggi dari pada kelas kontrol dengan menggunakan uji-t dengan rumus:

$$
\begin{aligned}
t=\frac{\overline{x_{1}}-\overline{x_{2}}}{S \sqrt{\frac{1}{n_{1}}+\frac{1}{n_{2}}}} & =\frac{60.682813-54.7228125}{3.389 \sqrt{\frac{1}{32}+\frac{1}{32}}} \\
& =\frac{5.96}{0.8473}=7.034
\end{aligned}
$$

Dengan $=0,05$ dan $d k=\mathrm{n}_{1}+\mathrm{n}_{2}-2=32+$ $32-2=62$, maka diperoleh $t_{\text {tabel }}(1.67)$ dengan selang kepercayaan 95\% sedangkan $t_{\text {hitung }}(7.034)$, $t_{\text {hitung }}(7.034)>t_{\text {tabel }}(1.67)$ maka hipotesis $H_{0}$ ditolak dan $H_{1}$ diterima sehingga dapat disimpulkan bahwa motivasi belajar siswa yang diajarkan dengan menggunakan model pembelajaran kooperatif tipe Pair Check disertai reward lebih tinggi daripada motivasi belajar siswa yang diajarkan dengan model pembelajaran konvensional.

\section{B. Kemampuan Penalaran Matematis Siswa}

Untuk memperoleh data mengenai kemampuan penalaran matematis siswa per indikator, dilakukan analisis terhadap masing- 
masing indikator kemampuan penalaran matematis siswa dengan menggunakan skor kelas eksperimen dan skor kelas kontrol yang dinilai berdasarkan rubrik penskoran kemampuan penalaran matematis dengan skala penilaian $0,1,2$ dan 3 .

Analisa butir item soal dilakukan meliputi validitas, daya beda, indek kesukaran, dan reliabilitas soal. Dari seluruh analisis, soal yang diujicobakan semuanya dapat digunakan.

Pada saat penelitian selesai dilakukan, dari tes kemampuan penalaran selesai diketahui bahwa nilai rata-rata kelas eksperimen yaitu 80,16 lebih tinggi dibanding nilai rata-rata kelas kontrol yaitu 74,13. Nilai maksimum hasil tes akhir kelas eksperimen adalah 98 dan kelas kontrol adalah 95, sedangkan nilai minimum kelas eksperimen adalah 50 dan kelas kontrol adalah 48. Simpangan baku kelas eksperimen adalah 11,67 lebih kecil dibandingkan dengan kelas kontrol yang memiliki simpangan baku sebesar 14,06. Hal ini menunjukkan bahwa pada kelas eksperimen kemampuan penalaran matematis siswa memiliki keragaman yang lebih kecil dari pada kemampuan penalaran matematis siswa kelas kontrol.

Dari Kriteria Ketuntasan Minimal (KKM) pada pembelajaran matematika yang ditetapkan di SMPN 19 Padang yaitu 80, terdapat 19 siswa mendapat nilai di atas KKM pada kelas ekperimen dan 15 orang pada kelas kontrol.

Adapun persentase distribusi jawaban siswa kelas eksperimen dan jawaban siswa kelas kontrol kemampuan penalaran matematis pada tiap indikator soal dapat dilihat pada Tabel 1.3:

Tabel 1.3 Data Tes Kemampuan Penalaran Matematis Setiap Butir Soal di Kelas Sampel

\begin{tabular}{|c|c|c|c|c|}
\hline \multirow{2}{*}{ No } & \multirow{2}{*}{ Indikator } & \multirow{2}{*}{ Soal } & \multicolumn{2}{|c|}{$\begin{array}{l}\text { Rata-Rata Untuk Setiap } \\
\text { Indikator }\end{array}$} \\
\hline & & & Eksperimen & Kontrol \\
\hline 1 & $\begin{array}{l}\text { Menyajikan pernyataan } \\
\text { matematika secara lisan, } \\
\text { tertulis, gambar, dan diagram. }\end{array}$ & $\begin{array}{c}1 a, 1 b, 2 a, 2 b, 7 a \\
7 b\end{array}$ & 92,19 & 79,51 \\
\hline 2 & $\begin{array}{l}\text { Mengajukan dugaan } \\
\text { (conjectures). }\end{array}$ & $3 a, 4,5,6 a, 6 b$ & 79,6 & 74,38 \\
\hline 3 & $\begin{array}{l}\text { Melakukan manipulasi } \\
\text { matematika. }\end{array}$ & $3 b, 3 b, 4,5,6 a, 7 a$ & 78,50 & 75,35 \\
\hline 4 & $\begin{array}{l}\text { Kemampuan menyusun bukti, } \\
\text { memberikan alasan/ bukti } \\
\text { terhadap kebenaran solusi }\end{array}$ & $1 a, 2 b, 2 b, 6 a, 7 b$ & 70,35 & 67,29 \\
\hline \multicolumn{3}{|c|}{ Rata-rata } & 80,16 & 74,13 \\
\hline
\end{tabular}

Dalam bentuk grafik, indikator sampel dapat juga dilihat pada Gambar 1.2 kemampuan penalaran matematis pada kelas berikut: 


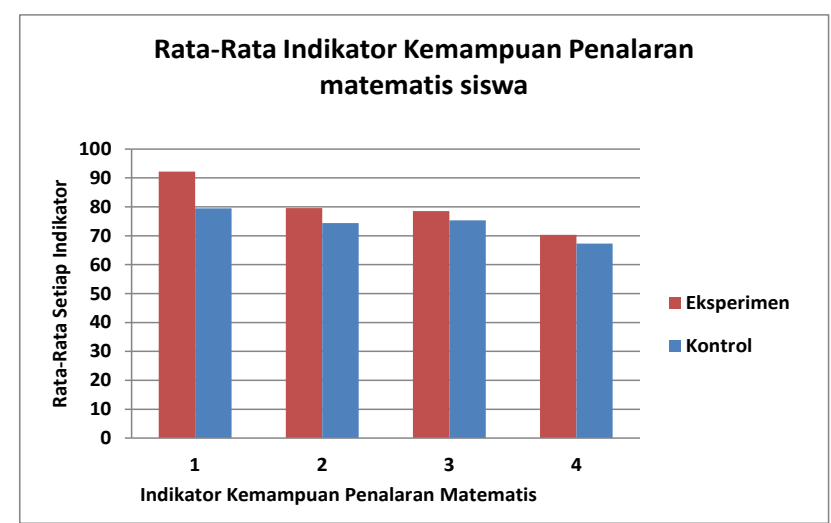

1.2 Grafik Persentase Rata-Rata Indikator Kemampuan Penalaran Matematis Siswa

Keterangan:

1. Menyajikan pernyataan matematika secara lisan, tertulis, gambar, dan diagram.

2. Mengajukan dugaan (conjectures).

3. Melakukan manipulasi matematika.

4. Kemampuan menyusun bukti, memberikan alasan/ bukti terhadap kebenaran solusi.

Berdasarkan grafik diatas dapat diketahui bahwa pada umumnya nilai rata-rata indikator kemampuan penalaran matematis siswa di kelas eksperimen lebih tinggi dibandingkan kelas kontrol. Maka dapat disimpulkan bahwa kemampuan penalaran metematis siswa pada kelas eksperimen lebih baik dibandingkan kelas kontrol. Hal ini berarti hasil kemampuan penalaran siswa yang diajarkan dengan pembelajaran kooperatif tipe Pair Check disertai reward lebih baik dibandingkan siswa yang diajarkan dengan model pembelajaran konvensional.

Untuk menguji kemampuan penalaran matematis siswa dilakukan analisis data akhir yaitu uji normalitas dan homgenitas. Berdasarkan analisis data, didapatkan signifikansi P-Value untuk kelas kontrol adalah 0,0819 dan kelas eksperimen adalah 0,0745.
Keduanya $>0,05$ sehingga terima Ho. Hal ini dapat diartikan bahwa data berdistribusi normal. Uji Homogenitas kelas sampel berdasarkan Tabel distribusi F didapatkan nilai $F_{\left(\alpha ; v_{1}, v_{2}\right)}$ untuk taraf nyat aa $=0,05$ dan derajat kebebasan $(d f)=\left(n_{1}-1, n_{2}-1\right)=(31,31)$ adalah 1.84. Maka diperoleh $F_{\text {hitung }}<F_{\left(\alpha ; v_{1}, v_{2}\right)} \approx$ $0,69<1,84$ sehingga dapat disimpulkan bahwa kedua kelas sampel memiliki variansi yang homogen.. Karena kelas sampel memiliki distribusi normal dan homogen maka untuk menguji hipotesis dapat dilakukan dengan uji-t.

Uji hipotesis digunakan untuk mengetahui kemampuan penalaran siswa pada materi fungsi dengan strategi pembelajaran Pair Check disertai Reward lebih tinggi dibandingkan dengan pembelajaran konvensional. pengolahan data dengan uji-t. dengan $\quad \alpha_{0.05}$ dan $d k=\left(n_{1}-1\right)+\left(n_{2}-\right.$ 1) $=(32-1)+(32-1)=62, \quad$ maka diperoleh $t_{\text {tabel }}=1,67$ dengan taraf kepercayaan 95\% sedangkan $t_{\text {hitung }}=1,867$. Karena $t_{\text {hitung }}>t_{\text {tabel }}$ maka hipotesis $H_{0}$ ditolak dan $\mathrm{H}_{1}$ diterima. Jadi kemampuan Penalaran Matematis siswa yang diajarkan dengan pembelajaran kooperatif tipe Tipe Check disertai Reward, lebih tinggi dari kemampuan Penalaran Matematis siswa yang diajarkan dengan pembelajaran konvensional.

\section{KESIMPULAN DAN SARAN}

\section{Kesimpulan}

1. Motivasi belajar siswa yang diajar dengan menggunakan model pembelajaran 
kooperatif tipe Pair Check disertai Reward, lebih tinggi dari pada motivasi siswa yang diajar dengan pembelajaran konvensional. Berdasarkan analisis angket dapat diketahui bahwa motivasi belajar matematika siswa kelas eksperimen yang diajar dengan model pembelajaran kooperatif tipe Pair Check disertai reward yaitu $87,44 \%$ dengan criteria baik sedangkan, pada kelas kontrol 73,0 \% dengan criteria cukup. Dengan uji hipotesis pada taraf kepercayaan 95\% adalah $t_{\text {hitung }}$ $(7.034)>t_{\text {tabel }}(1.67)$.

2. Kemampuan penalaran matematis siswa setelah diajar dengan model pembelajaran kooperatif tipe Pair Check disertai Reward lebih tinggi dari pada kemampuan penalaran matematis siswa yang diajar dengan menggunakan pembelajaran konvensional Rata-rata tes akhir siswa pada kelas eksperimen adalah 80,16 dan pada kelas kontrol 74,13. Jika dilihat dari ketuntasan hasil tes akhir siswa, pada kelas eksperimen terdapat 19 siswa atau sebanyak 59,38\% siswa yang memenuhi Kriteria Ketuntasan Minimun (KKM) dari 32 siswa yang ada. Sedangkan pada kelas kontrol terdapat 15 siswa atau sebesar $46,88 \%$ siswa yang nilainya mencapai KKM dari 32 siswa yang ada.

Berdasarkan perolehan nilai di atas dapat terlihat bahwa kemampuan penalaran matematis siswa pada kelas eksperimen lebih tinggi dari kemampuan penalaran matematis siswa kelas kontrol.
Saran

Berdasarkan kesimpulan yang diperoleh dari penelitian ini maka disarankan sebagai berikut:

1. Agar guru matematika khususnya guru matematika $\quad$ SMPN 19 Padang menerapkan model Pair Check untuk meningkatkan motivasi dan kemampuan penalaran matematis siswa pada pokok bahasan relasi dan fungsi.

2. Kepada para pembaca diharapkan agar hasil penelitian ini dijadikan sebagai salah satu wadah untuk memperkaya wawasan yang telah dimiliki.

3. Diharapkan kepada calon guru atau mahasiswa kependidikan untuk mengembangkan penelitian lanjutan model pembelajaran tipe ini.

4. Bagi peneliti berikutnya diharapkan mampu untuk menggunakan dan membagi waktu seefisien mungkin, sehingga proses pembelajaran dapat berjalan dengan lebih baik dan memberikan hasil yang lebih memuaskan

\section{DAFTAR PUSTAKA}

Arikunto, Suharsimi, Prosedur Penelitian Suatu Pendekatan Praktik, Jakarta: Rineka Cipta, 2010

---------, Dasar-Dasar Evaluasi Pendidikan, Jakarta: Bumi Aksara, 2009.

Praktik, Jakarta: $\quad$ Rineka Cipta, 2006
----- Prosedur Penelitian suatu Pendekatan 
Huda, Miftahul, Model-Model Pengajaran dan Pembelajaran, Yogyakarta: Pustaka Pelajar, 2014.

Ina Rosada Triwigati, Iswahyudi Joko Suprayitno dan Martyana Prihaswati, Keefektifan Model Pembelajaran Pair Check For Make A Match dengan Pendekatan Konatektual Terhadap Kemampuan Penalaran Pada Materi Segiempat Kelas VII, Prihaswati (Jurnal Pendidikan Matematika, 1 (April: 2016)

Iryanti, Puji, Penilaian Unjuk Kerja, Yogyakarta: Depdiknas, 2004.

Lubis, Syahron, Metodologi Penelitian Pendidikan, Padang: Sukabina Press,2011

Nursahimi, Desi Kumala Sari, Penerapan Model Pembelajaran Kooperatif Tipe Pair Check Untuk Meningkatkan Aktivitas Dan
Pemahaman Konsep Matematis Siswa Kelas VII Smpn 31 Padang Tahun Ajaran 2016/2017 (Skripsi: 2016)

Prayitno, Elida, Motivasi dalam Belajar, Padang: FKIP IKIP Padang,1989.

Riduwan, Metode dan Teknik Menyusun Tesis, Bandung: Alfabeta,2010.

Sarwono, Jonathan, http: //www. info/ teori_spss/msi) 08/11/2017.

Shadiq, Fajar, Kemahiran Matematika, Yogyakarta: Depdiknas, 2009

Sugiyono, metode penelitian pendidikan, Bandung: IKAPI, 2010

Uno, Hamzah B, Teori Motivasi dan pengukurannya, Jakarta: Bumi Aksara,2010 